\title{
THE IMPLEMENTATION OF PHYSICAL AND HEALTH EDUCATION IN SCHOOL
}

\author{
Kamal Firdaus \\ Padang State Uni versity, Komp. Parupuk Raya B.36 Tabing Padang West Sumatera 25171 \\ dr. Kamalfirdaus.mkes.aifo@gmail.com
}

\section{ABSTRACT}

Kamal Firdaus, December 2012. The Aplication Learning in General School.

The problem of this paper is about the facilities, utilities, teacher's quality and quantity, participation and extra work as well as the future is pledge of application of physical and healt education learning in general school.

The aims of this paper are physical domain, psychomotor, cognittif and affectif.

The conslusions of this paper are :

1. Training program developing sports is a part of an effort in increasing physical and spintual of human a quality.

2. The aim of physical education is oriented to the curriculum.

3. The aplication of physical education in school is an effort of athlete's talentskoting.

Suggestions of this paper are:

1. To keep balance between learning in one side and an effort of sport achievement increasing in another side.

2. The quantity and the quality of teachers is the main support to the process of teaching and learning.

There is the need inereasl the school facilities in quantity a well as the quality.

\section{Indexing terms/Keywords}

The Implementation Of Physical and Health Education in School.

\section{Academic Discipline And Sub-Disciplines}

\section{Sport Education}

SUBJECT CLASSIFICATION

Natural and Social

\section{Council for Innovative Research}

Peer Review Research Publishing System

Journal: International Journal of Research in Education methodology Vol. 7, No.3

iiremeditor@gmail.com

www.ijrem.com 


\section{INTRODUCTION}

Sport as a social-cultural phenomenon has rapidly increased and developed, so it can be said that as technology and science are advancing, consequently, sports are also needed to keep people's life in balance.

In addition, sport is an integral part in education which is able to give a valuable contribution toward the whole human's development for the rest of their live. In clause 4, National Education Regulation, no 2. Year 1989, it is stated that national education aims at improving the live of people and developing the citizen of Indonesia to be whole. Who are faithful to God Almighty, well-behaved, knowledgeable, skillful, healthy in terms of physical and spiritual, personally great and indepent, and responsible toward society and nationality.

In GBHN (1988) it is also stressed that the development of education is a part of improving the quality of indonesian in the purpose of enchancing physical and spiritual fitness for society, character, discipline and sportivity building, and increasing achievements in sports which can evoke the pride of the nation. In relation to these facts, it is necessary to improve physical education and sport in schools which develop sports, the effort in socialize sport and making them do it as a habit. It is also to create an environtment that support society to participate responsibly in educating and developing sports, especially in improving the training of the next candidate of athletes. ( for athlete's talent scouting )

The development of sport is a part of an effort to enchance the quality of indonesian, which is specialized in enhancing the physics and spirits of all people, character, discipline and sportivity building, and increasing achievements in sports which can evoke the pride of the nation. Thus, it can lead to these implication :

a. Physical education and sport will enhance the physical and spiritual fitness which led to improving human's quality.

b. Physical education and sport in school need to be improved

c. Physical education is a physical activity which led to the sport activity

d. Aside from enchancing physical and spiritual fitness, Physical and spiritual education also function as character, discipline, and sportivity building.

e. Physical education in school, should give a chance to socialize sport and make them do it as a habit that is reflected in the enhance of physical fitness.

f. Physical education in school, should be related with values of life, such as : sport habit and healthy life style.

g. Youth is the most keen moment in the effort to train athletes. Physical education teachers should be given a chance and skill as a coach in their school, which is implemented in school's policy.

\section{CHAPTER II \\ PHYSICAL AND HEALTH EDUCATION}

The aims of physical education in school is a part of National education's goal. Physical education that is applied today is oriented from the completion of the 1975 curriculum. Curriculum as an instrument to achieve the goals of education, in particular, and generally the aims of development are the implementation of GBHN. Along with the growth of development of science, technology and national development so the instrument to achieve the goal should be in line along with the demands of the progress itself.

Physical and health education is a process of education which encourages, guides, develops, and builds their physical and spiritual also the student's health and environment for them to live in harmony and optimally, so they are able to do their duty for themselves and national development.

The term "Sport and health education" has been changed into "physical education" as stated in Decree of Minister of Health and Culture no 0413/U/1987 that has been enforced for elementary, junior high, and senior high school curriculum. In the consideration of the Minister of Health and Culture decree, it is stated:

a. Physical education is an integral part from the whole education

b. Physical education aims to develop individual organic, neuromusculer, intelectual dan emotional

c. In the recent years, implementation of sport and health only teach about the basic movement and the basic skills, so it need to be improved.

Those consideration has shown the basic ideas to develop physical education system including the completion of existing curriculum. It is expected to begin on 1994.

On the other hand, if we put our attention on the limitation that has been created by UNESCO (1974). It is printed on Internationa charter of Physical Education, which are "Physical education is a person's education process as an individual or as a member of society which is done consiously and sistematically through various physical activity in order to enchance physical skills, intelligence growth, and personality build." A sistematically arranged learning material as the part of curriculum in form of a certain study which comes from elements of Athletic games, dance, exercise, martial arts that are adapted and chosen so that it can be implemented to the physical education pratice in schools are needed.

According to explanation above, it is clearer to see that to achieve a good physical education teaching in school, skillful professional educators are needed as qualified teachers on their own field. Because those teacher are expected to: 
1. Educate the students to be indonesian, based on Pancasila, who are able to manage himself and be responsible to the nation development

2. Provide the students with the ability to continue their study to the higher stage

3. Provide the student with the basic ability to live among the society and develop themselves according to their own talent and interest.

\section{CHAPTER III DISCUSSION}

The curriculum or education program of physical and health education which prioritizing in movements or physical activity based on the growth rates and development of students in the form of the introduction of preschool, basic movements, attitudes and habit on primary education as well as the development of knowledge and the ability on secondary education.

The success of implementaion of physical and health education, besides students' achievements who have good organic functions; neuromuscular junctions, intellectual and emotional, and psychological harmony, is highly dependent on:

1. the achievement of a healthy atmosphere / condition in the implementation of the program.

2. the realization of interaction of managers from the level of decision makers to coaches in the field and students.

3. the availability of adequate facilities and infrastructure as supporting for the implementation of the curriculum

4. the availability of sufficient numbers of teachers who are accompanied by satisfactory quality

In short, the purpose of what is expected and can be earned in physical and health education for students' ability namely:

\begin{tabular}{|c|c|c|c|c|c|c|c|c|c|c|}
\hline \multirow[t]{2}{*}{ No } & \multirow{2}{*}{$\begin{array}{l}\text { Dominant - dominant covered Physical } \\
\text { Education and Health }\end{array}$} & \multicolumn{3}{|c|}{ SD } & \multicolumn{3}{|c|}{ SMP } & \multicolumn{3}{|c|}{ SMA } \\
\hline & & $\mathbf{M}$ & $\mathbf{S}$ & $\mathbf{L}$ & $\mathbf{M}$ & $\mathbf{S}$ & $\mathbf{L}$ & $\mathbf{M}$ & $\mathbf{S}$ & $\mathbf{L}$ \\
\hline \multirow[t]{5}{*}{ A } & Physical domain & & & & & & & & & \\
\hline & 1. Strength & V & & & & V & & & & V \\
\hline & 2. Durability muscle & $\mathrm{V}$ & & & & $\mathrm{V}$ & & & & $\mathrm{V}$ \\
\hline & 3. cardio respiratory endurance & $\mathrm{v}$ & & & & $\mathrm{V}$ & & & & $\mathrm{V}$ \\
\hline & 4. Flexibility & $\mathrm{V}$ & & & & $\mathrm{V}$ & & & & $\mathrm{V}$ \\
\hline \multirow[t]{12}{*}{ B } & Psychomotor domain & 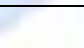 & & & & & & & & \\
\hline & 1. The ability of motion perceptual & & & & & & & & & \\
\hline & a. balance & V & V & & & V & & & & $\mathrm{V}$ \\
\hline & b. kinesthetic & $\mathrm{V}$ & $\mathrm{V}$ & & 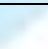 & $\mathrm{V}$ & 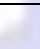 & & & $\mathrm{V}$ \\
\hline & C. visual & V & $\mathrm{V}$ & & & V & & 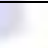 & & $\mathrm{V}$ \\
\hline & d. auditif & $\mathrm{V}$ & $\mathrm{V}$ & & & $\mathrm{V}$ & & & & $\mathrm{V}$ \\
\hline & e. Eye coordination and movement & V & 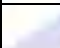 & 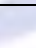 & & V & & & & V \\
\hline & f . tactile & V & & & & $\mathrm{V}$ & & & & $\mathrm{V}$ \\
\hline & 2. The basic movement skills & - & 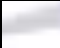 & & & & & & & \\
\hline & a. manipulative skills & $\mathrm{V}$ & & & & $\mathrm{V}$ & & & & $\mathrm{V}$ \\
\hline & b. Manipulative skills associated with the object & V & & & & V & & & & $\mathrm{V}$ \\
\hline & C. sports skills & $\mathrm{V}$ & & & & $\mathrm{V}$ & & & & $\mathrm{V}$ \\
\hline \multirow[t]{3}{*}{$\mathrm{C}$} & Cognitive domain & & & & & & & & & \\
\hline & 1. Cognitive & & & & & & & & & \\
\hline & 2. Reasoning & $\mathrm{V}$ & & & & $\mathrm{V}$ & & & & $\mathrm{V}$ \\
\hline \multirow[t]{4}{*}{$\mathrm{D}$} & Affective domain & & & & & & & & & \\
\hline & 1. The impact of physical activity on health & V & & & & V & & & & V \\
\hline & 2. Self-actualization & $\mathrm{V}$ & & & & $\mathrm{V}$ & & & & $\mathrm{V}$ \\
\hline & 3. Self-esteem & & & & & & & & & \\
\hline
\end{tabular}


Description :

$\mathrm{M}$ : Beginner, introduction dan development phase

$\mathrm{S}$ : Intermediate, development and improvement phase

L : Advance, mastering phase

Introduction : Introducing different movements, postures, objects and its properties.

Development : Developing the concepts or forms that are already known with modified it into more effective and efficient.

Mastering : Gaining control of the combination of space, time and shape

Note :

For further description of the goals, which are expected in physical and health education, can be seen in appendix 1 page 15.

\section{CHAPTER IV \\ PROBLEM}

Based on several kinds of the description above, which has been told in a practical manner, it is not necessarily can be carried out flawlessly. It is caused by some obstacles encountered in the field, they are:

a. Infrastructure

The school's field is not less than enough, especially for school located in larger cities. If a field is available, it will be used jointly by two or more at the same time. This situation will be difficult for teachers to implement sport activities well.

b. Equipments

The number of sports equipment that is owned by a school was very limited and the quality is low. In addition, the ratio between the tools available to the number of students in general is 1: 10, whereas a comparison between sports equipment and students ideally is $1: 2$.

c. Educator

The quantity of P.E. teacher in general is sufficient but another problem has arisen. The distribution of teachers in some cities is not spread evenly which makes some schools does not have any Physical Education teacher. The quality of P.E. teacher in accordance with scientific and technological development should be increased. Because no matter how excellent education curriculum applied, if it is not supported with a good quality teacher, students' achivements or interest will be lower.

d. Participation and extra efforts

To carry out the physical education in schools, the physical education teachers are aided by the school, the owner and a supervisor. However, those 3 elements are the ones who give difficulties for the teacher. So that, the authority of P.E. teachers to channel the talent and interest of the students are disturbed. In addition, most teachers in a school also serve as bodyguard for the principal which is essentially illegal. This additional job will reduce the thought and the attention to Physical Education activities at school.

e. Future promise

Students' interest will gradually reduced because of the thought from teachers and parents who put P.E. education as a subject which is not important, because it does not have an influence with students' report card. In addition, there are parents who delight if the children have good score in math that being able to do a 2,10 meters high jump. In fact, students who have sports' achivement find it hard to increase their grade, because they lack of intellectual competence.

By the fact that the parents are more likely oriented for their children future, academically, than to support their children for sport achievements whether at school or at the club.

\section{CHAPTER V \\ CONCLUSION AND ADVICE}

\section{A. Conclusion}

The development of sport is a part of an effort to enchance the quality of indonesian, which is specialized in enhancing the physics and spirits of all people, character, discipline and sportivity building, and increasing achievements in sports which can evoke the pride of the nation.

In addition, sport is an integral part in education which is able to give a valuable contribution toward the whole human's development for the rest of their live.

The aims of physical education in school is a part of National education's goal. Physical education that is applied today is oriented from the completion of the 1975 curriculum. Curriculum as an instrument to achieve the goals of education, in particular, and generally the aims of development are the implementation of GBHN. Along with the growth of development 
of science, technology and national development so the instrument to achieve the goal should be in line along with the demands of the progress itself.

The implementation of physical education in school is an effort of training athletes and socializing sports and also, implicitly, to make them do it as a habit. However, in fulfilling those goals there can be found some factors, either restricting or supporting, that influence it, such as :

a. Restricting Factors

1) Inadequate school field.

2) High-quality and expensive sport equipments are limited.

3) The placement of physical education teachers is not well-managed.

4) The effect of scores in physical education does not play a role in grading the students so the parents do not consider much about physical education.

b. Supporting Factors

1) Physical and Health Education has been included in the school curriculum.

2) The goverment has provided financial help for the sport facilities in school.

3) Even though the number of physical education teachers are not significant, at least they are available.

B. Advices

4) There are under-developments stadiums in several places.

According to the explanation from the conclusion, there are some advices that can be given :

1) To keep the balance between learning and the effort to increase students' sport achievements in school, socialization should be held for the parents in order to make them support the school's programs.

2) The quantity and the quality of physical education teachers which are the main support to the process of teaching and learning, should be improved through workshop.

3) There is the need in enhancing the school facilities in term of quantity or quality.

\section{REFERENCES}

[1] Ateng, Adul Kadir, (1991) "Ke Arah Pembentukan Sistem Pendidikan Jasmani Di Indonesia". FPOK IKIP Jakarta.

[2] Depdikbud, (1991) "Pendidikan Jasmani Dan Kesehatan SD, SLTP, dan SLTA". Balitbang Depdikbud, Jakarta.

[3] Depdikbud, (1991) "Pedoman Penyelenggaraan Pendidikan Prajabatan Program D II PGSD Guru Kelas". Dirjen Dikti, Proyek Pembinaan Tenaga Kependidikan Jakarta.

[4] GBHN, (1998) "Bahan Penataran Dan Bahan Referensi Penataran Pola 100 Jam”. Dirjen Dikti Depedikbud, Jakarta.

[5] Soemitro, (1991) "Implikasi Peraturan Perundangan Terhadap Pendidikan Jasmani Serta Rasional Kebutuhan Dan Pelaksanaan Pendidikan Jasmani Di Sekolah Dasar". FPOK IKIP Jakarta.

[6] Waliono, Hasan, (1998) "Penyelenggaraan Pendidikan Jasmani Dan Kesehatan Serta Pembinan Olahraga Di Sekolah Dalam Upaya Pembibitan Olahraga Nasional”. Dikdasmen Depdikbud, Jakarta.

[7] UNESCO, (1974) “Declaration on Sport” Paris, Place du Fontenoi.

\section{CURICULUM VITAE}

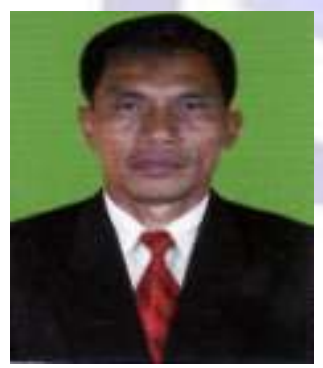

Firdaus Kamal, born in Jambi 12 Novembers 1962, was the second of Mr. H. Sutan Pameran (Alm)and Mrs. Hj. Elzas M. (from Bukittinggi).

Married to Agus nelly and happing a child nam ed Rahmat Al Azi z katialy, Student of Pembangunan

UNP Senior High School.

Education finish his Primary School in SD Negeri 01 Bajubang Jambi in 1975, High School in Bajubang Jam bi in 1978, Senior Figh School in Bajubang Jam bi in 1981, and Sport Science Faclity, Ins titute a Science Theacher and Science Education of Padang in 1985, in 1997 continued Megister Program Sport Science in Airlangga Univercity and finisehed 1999, in 2009 continued Doctor

Program Sport Education Studies in Semarang Univercity and finished 2012.

In 1987 appointed School Theacher Gym Teacher and in 1990 moved to the transition to Institute a Science Theacher and Science Education of Padang until now.

Scientific Activities, Sport Science Thecnology (Scientific Papers, 1998), PB Pelti Instructur (Workshop, 1994), The Role of Secology, Ps ychology and Sports Bisiness in Supporting the Im provem en of Sports Performence (Sympos ium, 1997), Internas ional Tenis Federation Coaching Works hop (2000), Inters ection Scientific Work of Science and Thecnology of Sports (Workshop, 2007).

Scientific Work (Book), General Science of Sport (UPI Bandung, 2003), Sports Marketing (UPI Bandung, 2006), Sport

Management (UPI Bandung, 2008). 